\title{
Studies into the synthesis of forskolin intermediates by electrocyclisation of allene-sulfoxides
}

\author{
A. Khodabocus \\ Department of Chemistry, University of Mauritius, Reduit, Mauritius \\ E-mail:ahmadk@condor.uom.ac.mu
}

(received 12 Apr 00; accepted 26 Nov 00; published on the web 04 Dec 00)

\begin{abstract}
Ionone has been converted into bicyclic triene-sulfoxides (10), (16) and (18) by elctrocyclisation of the corresponding divinyl allenesulfoxides (9), (15) and (17) respectively. Reduction of bicycle (18) by lithium aluminium hydride gave alcohol (19) by a novel fragmentation.
\end{abstract}

Keywords: Ionone derivatives, allene-sulfoxide electrocyclisation

\section{Introduction}

Forskolin (1) is a highly oxygenated diterpene isolated from methanolic extract of the Indian plant Coleus forskohlii by de Souza et al. ${ }^{1}$ The molecule displayed very interesting physiological properties: thus it exhibits potent positive inotropic activity and blood pressure lowering properties. In clinical studies, forskolin has shown considerable potential for the treatment of glaucoma, congestive heart failure and bronchial asthma. ${ }^{2,3}$ Its potential as a drug coupled with its structural complexity have made forskolin the subject of much synthetic effort. ${ }^{4-16}$

The use of allene sulfoxide electrocyclisation reactions in synthesis has been developed and exploited by Okamura and co-workers.17 Thus it was shown that the dienol (2) could be smoothly converted into the bicyclic compound (3) by treatment with phenylsulfenyl chloride (Fig. 1). 


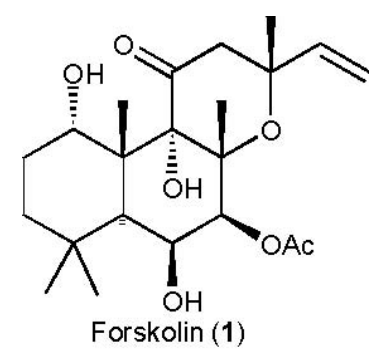

Further transformations carried out on the cyclisation product suggest that such a protocol could be used for an approach to oxygenated terpenoids such as forskolin.
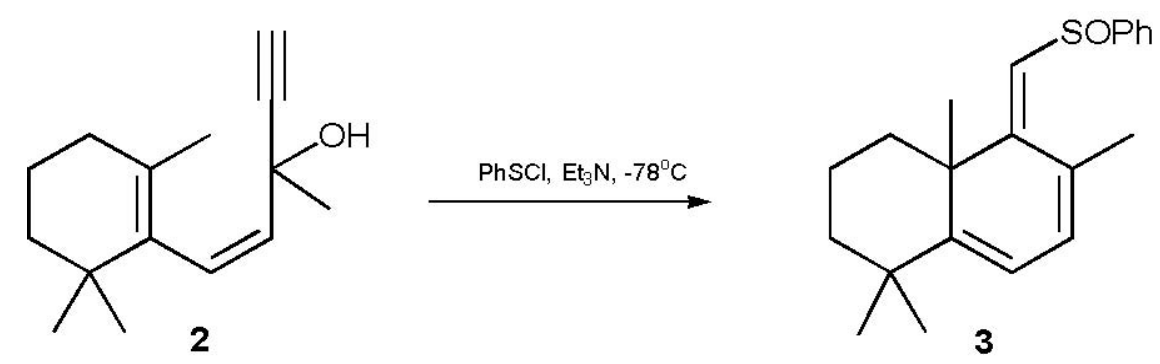

\section{Figure 1}

Thus it was speculated that a suitable ionone derivative with the requisite oxygenfunctionality in the ring destined to become the ring A of the natural product could be used for the Okamura cyclisation to generate the required bicyclic substance which would then be transformed into a forskolin precursor (Fig. 2). 

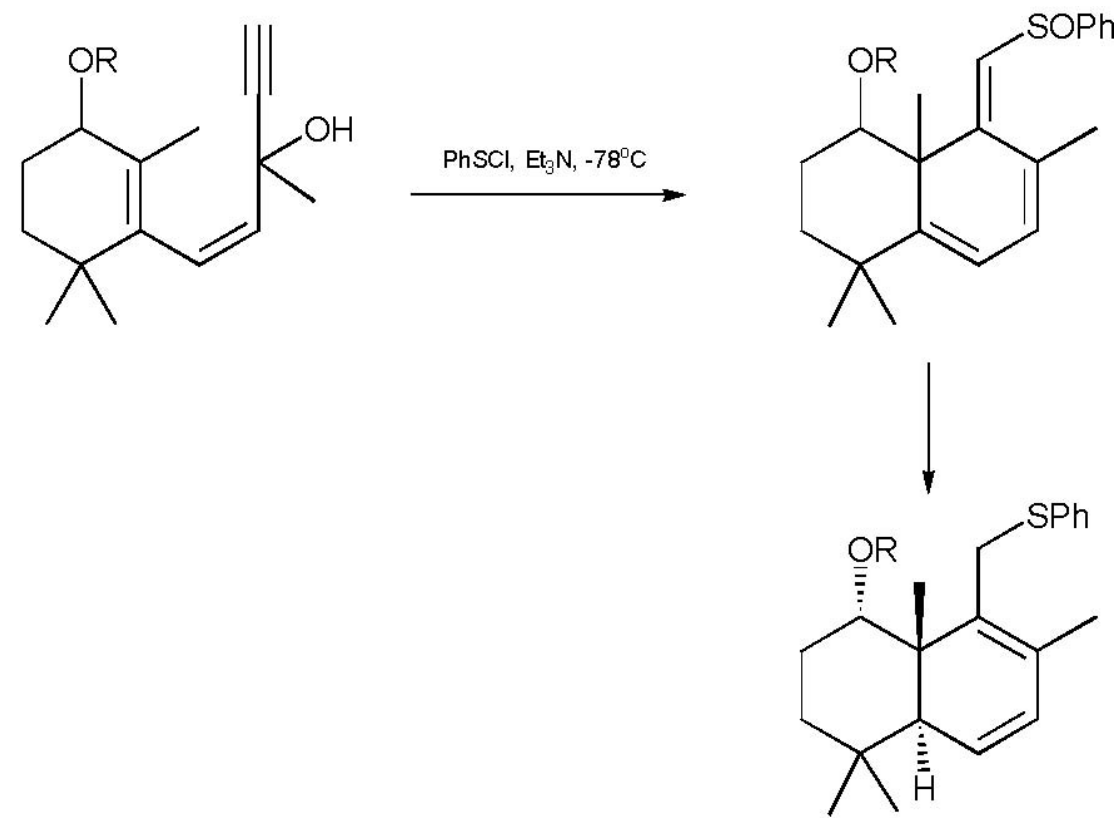

Figure 2

\section{Results and Discussion}

With this in mind $\alpha$-ionone (4) was epoxidised regioselectively using m-chloroperbenzoic acid and the resulting epoxide (5) was isomerised to the corresponding hydroxyionone derivative (6) by treatment with potassium carbonate in hot methanol. The hydroxyl group was then protected as the t-butyldimethylsilyl ether (7) according to the Corey-Venkateswarlu procedure. ${ }^{18}$ The ketone (7) was then transformed into the required acetylene-alcohol (8) by simply treating it with lithium acetylide - ethylene diamine complex. This furnished the product in rather modest yield $(<50 \%)$ after purification by silica gel chromatography. As this was a very slow reaction and a lot of unconsumed starting material was isolated, a modified protocol was investigated. Thus when the ketone (7) was treated with lithium trimethylsilylacetylide at $-78^{\circ} \mathrm{C}$ and the trimethylsilylacetylene moiety protodesilylated with catalytic potassium carbonate in methanol the desired product was now obtained in $90 \%$ overall yield. The olefinic protons of (8) appeared as doublets at 5.60 and $6.40 \mathrm{ppm}(\mathrm{J}=16 \mathrm{~Hz})$. The compound $(\mathbf{8})$ was then photoisomerised in the presence of acetophenone as sensitiser to give the corresponding cis isomer (9) in nearly quantitative yield as a 1:1 mixture of diastereoisomers. The ${ }^{1} \mathrm{H}$ NMR spectrum of the product clearly showed that isomerisation had occurred as the olefinic protons now resonated at 5.86 ppm as a pair of very close doublets $(\mathrm{J}=12 \mathrm{~Hz})$, appearing as a multiplet for one diastereoisomer 
and two separate doublets at 5.54 and 5.56 respectively $(\mathrm{J}=12 \mathrm{~Hz})$ for the other. When this mixture of alcohols was treated with phenylsulfenyl chloride in the presence of triethylamine (TEA) at $-78^{\circ} \mathrm{C}$, a rapid reaction ensued as evidenced by the almost instantaneous disappearance of the orange colour of the reagent and a mixture of isomers (10) was obtained in $75-80 \%$ yield (Fig. 3).

No attempt was made to determine the composition of the mixture. Nevertheless upon purification by chromatography, one of these isomers was isolated in the pure form as a crystalline solid and exhibited olefinic signals at 5.98 (singlet, $1 \mathrm{H}$ ) and 6.08 (broad singlet, 2H) $\mathrm{ppm}$. The methine proton of the silyl ether resonated at $3.92 \mathrm{ppm}$ as a broad doublet $(\mathrm{J}=4.0 \mathrm{~Hz})$ indicating an axial silyloxy group in this isomer.

Reaction of the sulfoxide mixture (10) with lithium aluminium hydride at ambient temperature was very sluggish, so refluxing dimethoxyethane was used as medium. Under these conditions a product mixture containing the required diene sulphide (11) as a 1:1 mixture of diastereomers, was obtained. However, it was also evident that substantial sulphide cleavage had occurred on account of the strong odour of thiophenol during work up. The allylic methylene in the NMR spectrum of (11) appeared as two distinct $\mathrm{AB}$ quartets: one at $4.15 \mathrm{ppm}$ and the other at $3.65 \mathrm{ppm}$. The olefinic hydrogens appeared as multiplets at $5.72 \mathrm{ppm}$ and $5.90 \mathrm{ppm}$ and the carbinolic proton as a broad singlet at $4.06 \mathrm{ppm}$ for the axial silyloxy group and as a doublet of doublet at $4.38 \mathrm{ppm}(\mathrm{J}=12 \mathrm{~Hz}$ and $6 \mathrm{~Hz}$ for axial-axial and axial-equatorial couplings respectively) for the equatorial isomer. 
<smiles>CC(=O)/C=C/C1C(C)=CCCC1(C)C</smiles><smiles>[R5]OC1CCC(C)(C)C(/C=C/C(C)=O)=C1C</smiles><smiles>C#CC(C)(O)C=CC1=C(C)C(O[AsH3])CCC1(C)C</smiles>

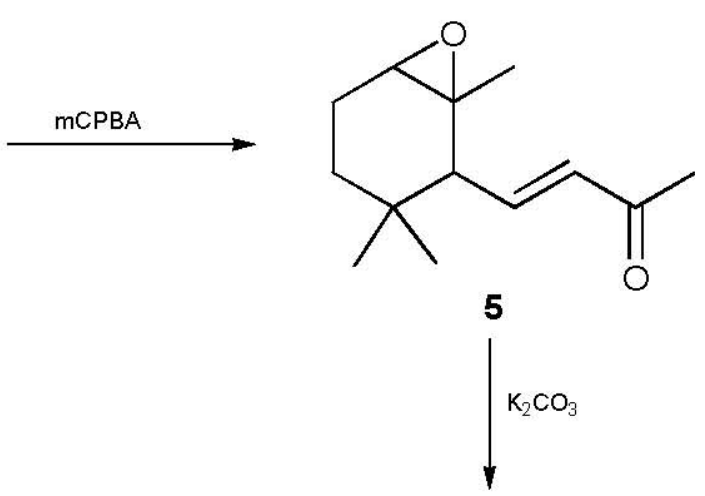<smiles>CC(=O)/C=C/C1=C(C)C(O)CCC1(C)C</smiles>

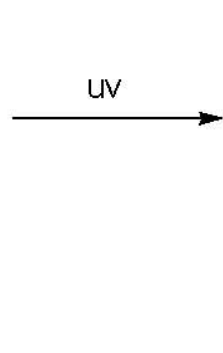

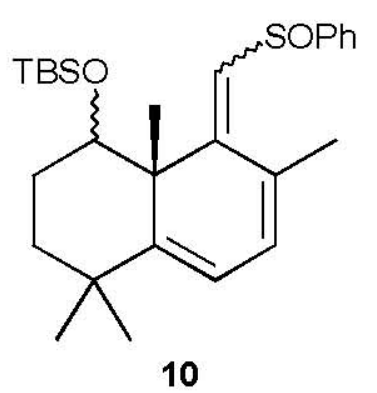

Figure 3 
At this stage it was intended to convert the sulphide into a sulfoxide (12) in order to perform a Pummerer rearrangement ${ }^{19}$ to aldehyde (13). Unfortunately upon treatment of the sulphide mixture with m-chloroperbenzoic acid, only a 40\% yield of the required sulfoxide (12) was obtained and when the latter was treated with acetic anhydride to induce a Pummerer ${ }^{19}$ rearrangement none of the desired product was obtained (Fig 4).

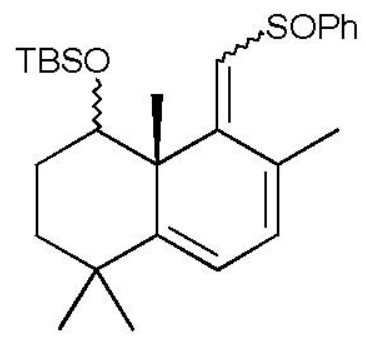

10

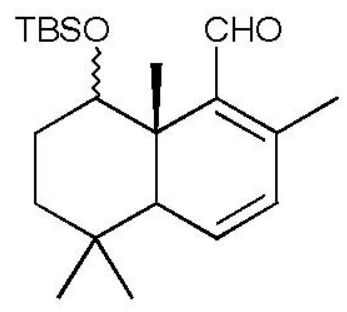

13

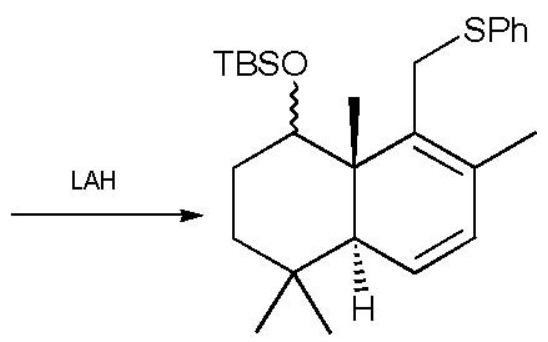

11

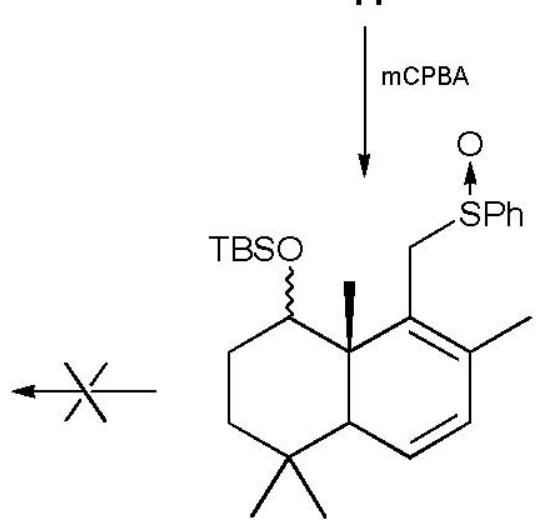

12

\section{Figure 4}

At this stage it was felt that the silyloxy group was possibly the source of our problem in view of its steric bulk. Therefore it was decided to revert to a sterically less demanding protecting group and the benzyloxymethyl group was judged to be a suitable candidate. The alcohol (9) was deprotected using TBAF (Fig 5) to furnish the diol (14) and this was selectively protected as the benzyloxymethyl ether (15) by treatment with benzyloxymethyl chloride in the presence of diisopropylethylamine. Exposure to phenylsulfenyl chloride gave the expected mixture of sulfoxides (16) in $70 \%$ yield. However, little progress was made, as transformations on this mixture also proved problematic.

Next, the sequence was repeated with the monoacetate (17) of alcohol (14), this was prepared in $76 \%$ yield by exposure to a mixture of acetic anhydride, pyridine and DMAP at $0^{\circ} \mathrm{C}$. Upon treatment with phenylsulfenyl chloride in the usual manner, the desired sulfoxide mixture (18) was obtained in $70 \%$ yield (Fig 6). 

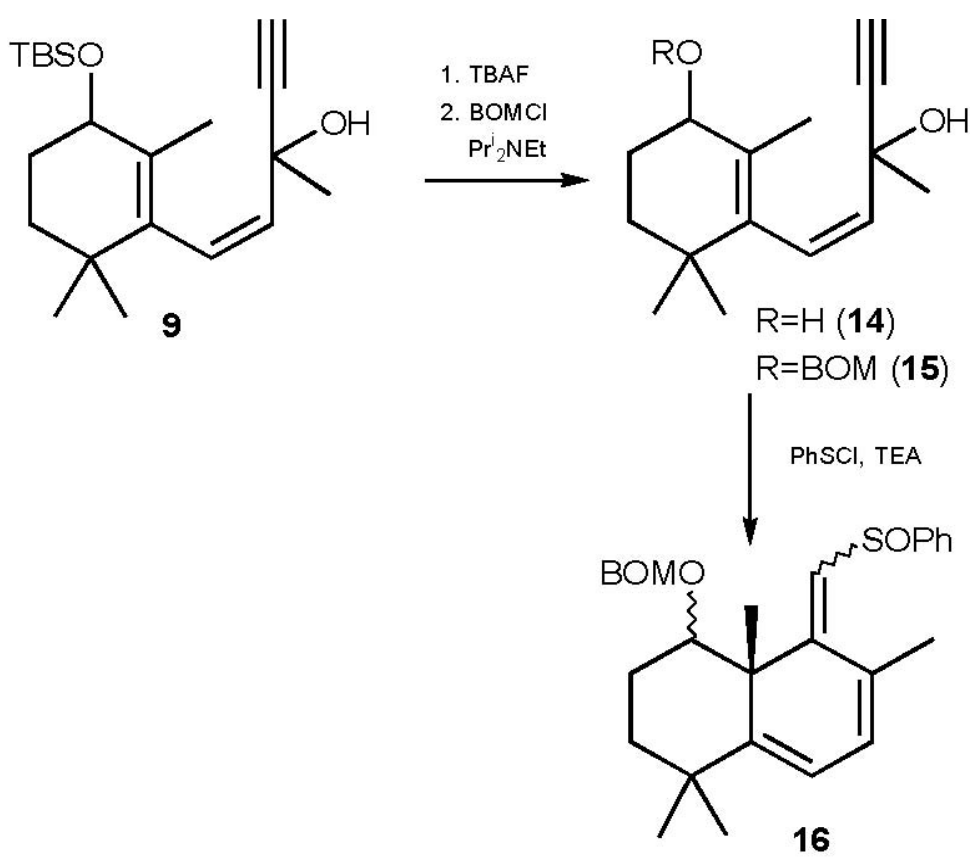

Figure 5

One separable component of the mixture displayed the following signals in the NMR: the exocyclic hydrogen as a singlet at $5.95 \mathrm{ppm}$, the other olefinic protons as overlapping doublets at $5.80 \mathrm{ppm}(\mathrm{J}=6 \mathrm{~Hz})$. When sulfoxides (18) were reduced with LAH, a clean product (19) was obtained. It had the following signals in the NMR spectrum: methyl singlets at $2.35 \mathrm{ppm}$ and $2.50 \mathrm{ppm}$, a triplet at $3.48 \mathrm{ppm}(\mathrm{J}=6 \mathrm{~Hz})$, a singlet at $4.15 \mathrm{ppm}$ and significantly no olefinic signals but instead an aromatic multiplet for seven hydrogens at $7.15 \mathrm{ppm}$. All these data are consistent with (19) being an undesired alcohol obtained by a fragmentation reaction, which one can envisage as having been initiated by attack of a hydride at the carbonyl group (Fig 7).

This can be considered as a novel fragmentation and is akin to the previously reported formation of the phenolic acid (20) from the bicyclic compound (21) ${ }^{20}$ in an attempted electrocyclisation of the acid (22) via its vinylketene (Fig 8). 
<smiles>C#CC(C)(O)/C=C\C1=C(C)C(O)CCC1(C)C</smiles><smiles>C#CC(C)(O)/C=C\C1=C(C)C(OC)CCC1(C)C</smiles><smiles>CC1=CC=C2C(C)(C)CC[C@@H](O)[C@]2(C)/C1=C/S(=O)(=O)O</smiles>

Figure 6<smiles>CC(=O)OC1CCC(C)(C)C2=CC=C(C)/C(=C\S(=O)(=O)O)C21C</smiles>

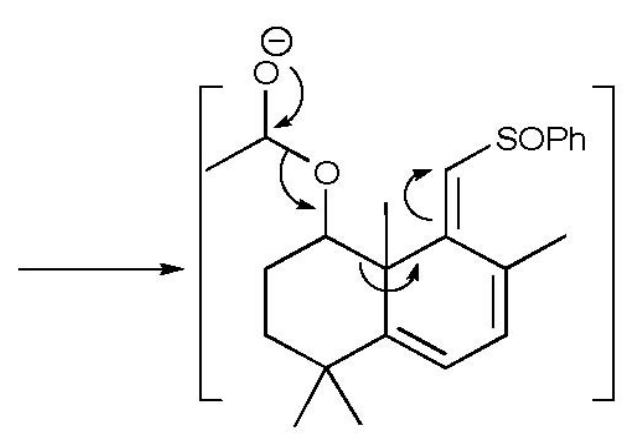<smiles>Cc1ccc(C(C)(C)CCCO)c(C)c1C[SbH]</smiles><smiles>CCCC(C)(C)c1ccc(C)c(S(=O)(=O)O)c1C</smiles>

Figure 7 
<smiles>CC1=C(/C=C\C(C)C(=O)O)C(C)(C)CCC1=O</smiles>

22

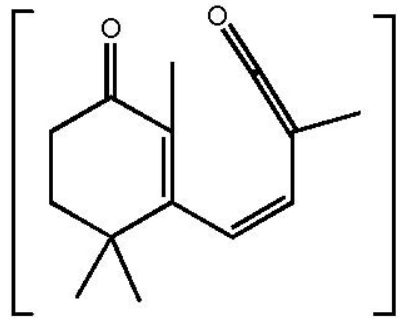

1
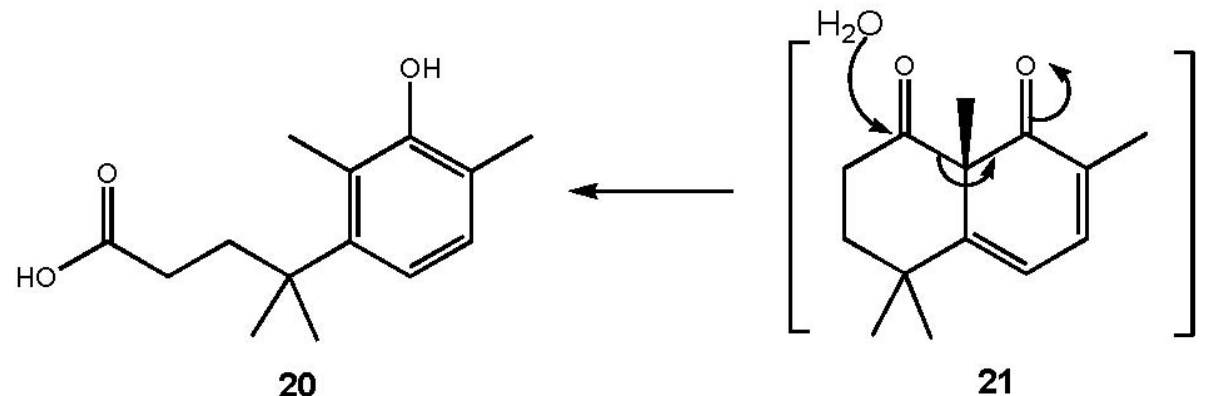

21

\section{Figure 8}

In conclusion it can be said that the allenesulfoxide electrocyclisation reaction provides a good method to assemble a cyclohexadiene system compatible with the skeleton of natural products like forskolin. More work is however required for the further transformation of the cyclised products into suitable synthetic precursors.

\section{Experimental Section}

General Procedures. Infrared spectra were run as thin films. The NMR spectra were run at 300 $\mathrm{MHz}$ for ${ }^{1} \mathrm{H} \mathrm{NMR}$ in $\mathrm{CDCl}_{3}$ solution using tetramethylsilane (TMS) as internal standard. Mass spectra and high-resolution mass spectra (HRMS) were measured using the electron impact (EI) technique. Chromatography refers to the flash column technique over Merck Kiesel gel $60 \mathrm{H}$ (230-400 mesh) and thin layer chromatography was carried out using plates precoated with Merck silica $60 \mathrm{~F}_{254}$. Ether and petrol (fraction boiling between $40^{\circ}$ and $60^{\circ} \mathrm{C}$ ) were distilled prior to use. Tetrahydrofuran was dried by refluxing over sodium and benzophenone under nitrogen and then distillation. Benzene, toluene, dichloromethane and acetonitrile were dried by 
refluxing over calcium hydride and then distillation.

Preparation of (3E)-4-[3-hydroxy-2,6,6-trimethylcyclohex-1-enyl]-3-buten-2-one (6). MCPBA (5.83 g; $33.8 \mathrm{mmol})$ and sodium bicarbonate $(2.7 \mathrm{~g})$ were placed in a flask containing methylene chloride $(80 \mathrm{ml})$ cooled to $-15^{\circ} \mathrm{C}$ under nitrogen. The cold stirred suspension was treated dropwise with a solution of $\alpha$-ionone ( $90 \%$ pure; $4.10 \mathrm{~g} ; 2.5 \mathrm{mmol}$ ) in methylene chloride $(10 \mathrm{ml})$. Then the reaction mixture was stirred for about eight hours with gradual warming to room temperature. The solid was filtered off and the filtrate was successively washed with saturated sodium carbonate solution $(1 \times 25 \mathrm{ml})$, sodium metabisulphite solution $(1 \times 25 \mathrm{ml})$ and finally brine $(1 \times 25 \mathrm{ml})$. The organics were dried $\left(\mathrm{Na}_{2} \mathrm{SO}_{4}\right)$ and concentrated to give the crude epoxide as a pale yellow oil (4.80 g; ca 100\%), which was suitable for the next stage. The compound had $\delta_{\mathrm{H}}\left(\mathrm{CDCl}_{3} ; 300 \mathrm{MHz}\right) 6.65(1 \mathrm{H}, \mathrm{dd}, \mathrm{J}=16.0 \mathrm{~Hz}$ and $9.0 \mathrm{~Hz}), 6.00(1 \mathrm{H}, \mathrm{d}, \mathrm{J}=16.0$ Hz), 3.05 (1 H, bt, J=2.0 Hz), 2.25 (3 H, s), 2.00 (1 H, d, J=9.0 Hz), 2.20-1.30 (4 H, m); 1.20 (3 $\mathrm{H}, \mathrm{s}), 0.90(3 \mathrm{H}, \mathrm{s}), 0.75(3 \mathrm{H}, \mathrm{s})$.

The foregoing epoxide was then dissolved in AR methanol $(50 \mathrm{ml})$ and the solution was treated with anhydrous potassium carbonate (4-fold excess). The resulting orange mixture was refluxed for 4-5 hours. Then most of the methanol was evaporated and the residue was dissolved in ethyl acetate $(100 \mathrm{ml})$. The organics were washed successively with water and brine and then dried $\left(\mathrm{Na}_{2} \mathrm{SO}_{4}\right)$. The solution was then evaporated and the residue was chromatographed on silica gel $\left(40 \% \mathrm{Et}_{2} \mathrm{O} /\right.$ petrol to $80 \% \mathrm{Et}_{2} \mathrm{O} /$ petrol) to give the title compound (6) as a pale yellow oil (3.00 g; 60\% from $\alpha$-ionone); $v_{\max } / \mathrm{cm}^{-1}$ (FT) (thin film) 3415,1665,1604; $\delta_{\mathrm{H}}\left(\mathrm{CDCl}_{3} ; 300 \mathrm{MHz}\right.$ ) $7.15(1 \mathrm{H}, \mathrm{d}, \mathrm{J}=16.0 \mathrm{~Hz}) ; 6.53(1 \mathrm{H}, \mathrm{d}, \mathrm{J}=16.0 \mathrm{~Hz}) ; 3.95(1 \mathrm{H}, \mathrm{bm}) ; 2.25(3 \mathrm{H}, \mathrm{s}) ; 2.00-1.20$ (4 $\mathrm{H}, \mathrm{m}) ; 1.82$ (3 H, bs); $1.05(3 \mathrm{H}, \mathrm{s}) ; 1.02(3 \mathrm{H}, \mathrm{s})$.

Preparation of (3E)-4-[3-t-Butyldimethylsilyloxy-2,6,6-trimethylcyclohex-1-enyl]-3-buten2-one (7). Hydroxyionone (6) (2.00 g; $9.615 \mathrm{mmol}$ ) was dissolved in dry DMF (8 $\mathrm{ml})$; the solution was charged with t-butyldimethylsilyl chloride $(2.00 \mathrm{~g} ; 12.734 \mathrm{mmol})$ and imidazole $(1.30 \mathrm{~g} ; 19.118 \mathrm{mmol})$. The mixture was stirred at ambient temperature under nitrogen for $3-4 \mathrm{~h}$ and then it was taken up in water $(25 \mathrm{ml})$. The solution was extracted with ether $(2 \times 50 \mathrm{ml})$, the combined extracts washed with brine $(3 \times 25 \mathrm{ml})$ and dried $\left(\mathrm{Na}_{2} \mathrm{SO}_{4}\right)$. The solvent was evaporated and the residue was purified by chromatography ( $4: 1$ petrol/ether) to give the product as a yellow oil (2.86 g; 92\%); $v_{\max } / \mathrm{cm}^{-1}$ (FT) (thin film) 1676, 1611; $\delta_{\mathrm{H}}\left(\mathrm{CDCl}_{3} ; 300 \mathrm{MHz}\right) 7.15(1 \mathrm{H}, \mathrm{d}$, $\mathrm{J}=16 \mathrm{~Hz}), 6.00(1 \mathrm{H}, \mathrm{d}, \mathrm{J}=16 \mathrm{~Hz}), 4.00(1 \mathrm{H}, \mathrm{bt}), 2.25(3 \mathrm{H}, \mathrm{s}), 2.00-1.20(4 \mathrm{H}, \mathrm{m}), 1.75(3 \mathrm{H}, \mathrm{bs})$, $1.00(3 \mathrm{H}, \mathrm{s}), 0.90(9 \mathrm{H}, \mathrm{s}), 0.10(6 \mathrm{H}, \mathrm{s})$

Preparation of 5-[2,4,4-Trimethyl-1-t-butyldimethylsilyloxycyclohex-3-enyl]-3-methylpent(E)-4-en-1-yn-3-ol (8). A flame dried 100-ml 2-neck flask was charged with dry THF (40.0 ml) and kept under nitrogen. The flask was cooled to $-78^{\circ} \mathrm{C}$ and trimethylsilylacetylene $(2.455 \mathrm{ml}$, $17.764 \mathrm{mmol}$ ) was transferred into it via syringe followed by dropwise addition of a $1.6 \mathrm{M}$ solution of butyl lithium in hexanes $(10.0 \mathrm{ml}, 16.0 \mathrm{mmol})$. The solution was stirred at $-78^{\circ} \mathrm{C}$ for 
$30 \mathrm{~min}$ and then allowed to warm up to $0^{\circ} \mathrm{C}$ over $15 \mathrm{~min}$. It was subsequently cooled to $-78^{\circ} \mathrm{C}$ and treated with a solution of ketone (7) $(2.860 \mathrm{~g}, 8.882 \mathrm{mmol})$ in dry THF (10.0 ml) dropwise. The reaction mixture was stirred at $-78^{\circ} \mathrm{C}$ for about $2 \mathrm{~h}$. The reaction was carefully quenched by addition of aqueous ammonium chloride solution $(25.0 \mathrm{ml})$. The layers were partitioned and the aqueous phase was extracted with ether $(2 \times 25 \mathrm{ml})$ and the extracts dried $\left(\mathrm{Na}_{2} \mathrm{SO}_{4}\right)$. The solution was evaporated and the residue was dissolved in methanol $(25 \mathrm{ml})$. The solution was saturated with anhydrous potassium carbonate (ca. $2 \mathrm{~g}$ ) and the mixture was stirred at ambient temperature for three hours whereupon TLC (5:1 petrol/ ether) showed complete reaction. The solid was filtered off and the solvent was evaporated to near dryness. The residue was dissolved in ethyl acetate $(75 \mathrm{ml})$ and washed successively with water $(2 \times 25 \mathrm{ml})$, brine $(25 \mathrm{ml})$ and dried $\left(\mathrm{Na}_{2} \mathrm{SO}_{4}\right)$. The solvent was evaporated and the residue was purified by chromatography $(5: 1$ petrol/ ether) to give the product as a pale yellow oil $(2.77 \mathrm{~g}, 90 \%) ; v_{\max } / \mathrm{cm}^{-1}$ (FT) (thin film) $3312,3270,2170 ; \delta_{\mathrm{H}}\left(\mathrm{CDCl}_{3} ; 300 \mathrm{MHz}\right) 6.40(1 \mathrm{H}, \mathrm{d}, \mathrm{J}=16.0 \mathrm{~Hz}), 5.60(1 \mathrm{H}, \mathrm{d}, \mathrm{J}=16.0 \mathrm{~Hz}), 4.00$ $(1 \mathrm{H}, \mathrm{t}, 5.0 \mathrm{~Hz}), 2.52(1 \mathrm{H}, \mathrm{s}), 1.90-1.10(4 \mathrm{H}, \mathrm{m}), 1.70(3 \mathrm{H}, \mathrm{s}), 1.60(3 \mathrm{H}, \mathrm{s}), 1.02(3 \mathrm{H}, \mathrm{s}), 0.95(3 \mathrm{H}$, s), $0.90(9 \mathrm{H}, \mathrm{s}), 0.10(6 \mathrm{H}$, two very close singlets).

Preparation of 5-[2,4,4-Trimethyl-1-t-butyldimethylsilyloxycyclohex-3-enyl]-3-methylpent(Z)-4-en-1-yn-3-ol (9). The trans diene (8) (2.00 g, $5.586 \mathrm{mmol}$ ) and acetophenone (spatula tip) were dissolved in dry benzene $(200 \mathrm{ml})$. The solution was degassed by bubbling nitrogen through it for about $10 \mathrm{~min}$. Then it was irradiated for $5 \mathrm{~h}$ under nitrogen using a medium pressure mercury lamp. The solution was subsequently concentrated to afford the crude cisdiene, which was used without further purification. The compound had: $v_{\max } / \mathrm{cm}^{-1}$ (FT) (thin film) 3528, 3312, 2100; $\delta_{\mathrm{H}}\left(\mathrm{CDCl}_{3} ; 300 \mathrm{MHz}\right) 5.86(1 \mathrm{H}, \mathrm{dm}, \mathrm{J}=12.0 \mathrm{~Hz}), 5.54(0.5 \mathrm{H}, \mathrm{d}, \mathrm{J}=12.0$ $\mathrm{Hz}), 5.56(0.5 \mathrm{H}, \mathrm{d}, \mathrm{J}=12.0 \mathrm{~Hz}), 3.98(\sim 0.5 \mathrm{H}, \mathrm{t}, \mathrm{J}=5.0), 3.92(\sim 0.5 \mathrm{H}, \mathrm{m}), 2.50(1 \mathrm{H}, \mathrm{s}), 1.90-1.20$ $(4 \mathrm{H}, \mathrm{m}), 1.72(3 \mathrm{H}, \mathrm{s}), 1.60(3 \mathrm{H}, \mathrm{s}), 1.00(3 \mathrm{H}, \mathrm{s}), 0.95(3 \mathrm{H}, \mathrm{s}), 0.90(9 \mathrm{H}, \mathrm{s}), 0.10(6 \mathrm{H}$, two very close singlets).

Cyclisation of compound (9). A 50-ml two-neck flame dried flask was charged successively with dry methylene chloride $(30 \mathrm{ml})$; alcohol (9) $(1.500 \mathrm{~g}, 4.310 \mathrm{mmol})$ and dry triethylamine $(1.300 \mathrm{ml}, 9.482 \mathrm{mmol})$. The solution was cooled to $-78^{\circ} \mathrm{C}$ under nitrogen. Phenylsulfenyl chloride $(0.747 \mathrm{~g}, 5.172 \mathrm{mmol})$ in dry methylene chloride $(2 \mathrm{ml})$ was added dropwise whereupon its orange colour was spontaneously discharged. When addition was completed, the pale yellow solution was stirred for $30 \mathrm{~min}$ at $-78^{\circ} \mathrm{C}$ and then allowed to warm up to ambient temperature over $30 \mathrm{~min}$. The reaction was quenched by addition of aqueous sodium bicarbonate solution (15 $\mathrm{ml}$ ). The layers were partitioned and the aqueous phase was extracted with a further portion of methylene chloride $(20 \mathrm{ml})$. The combined organics were washed (brine) and dried $\left(\mathrm{Na}_{2} \mathrm{SO}_{4}\right)$. Evaporation and purification of the crude product by chromatography $(20 \%$ petrol/ ether $->80 \%$ ether/ petrol) gave a mixture of diastereomers (1.344 g, yellow syrup) and a pure sample of the most polar diastereomer $(0.215 \mathrm{~g}, 79 \%$ combined yield $)$. The latter compound had: $\delta_{\mathrm{H}}\left(\mathrm{CDCl}_{3}\right.$; 
$300 \mathrm{MHz}) 7.75\left(2 \mathrm{H}, \mathrm{dd}, \mathrm{J}=8.0 \mathrm{~Hz}\right.$ and $\left.\mathrm{J}{ }^{\prime}=2.0 \mathrm{~Hz}\right), 7.46(3 \mathrm{H}, \mathrm{d}, \mathrm{J}=8.0 \mathrm{~Hz}$ overlapping a multiplet), $6.08(2 \mathrm{H}, \mathrm{bs}), 5.98(1 \mathrm{H}, \mathrm{s}), 3.92(1 \mathrm{H}, \mathrm{d}, \mathrm{J} \sim 4.0 \mathrm{~Hz}), 2.40(3 \mathrm{H}, \mathrm{s}), 2.30-1.20(4 \mathrm{H}, \mathrm{m})$, $1.35(3 \mathrm{H}, \mathrm{s}), 1.25(3 \mathrm{H}, \mathrm{s}), 1.20(3 \mathrm{H}, \mathrm{s}), 0.60(9 \mathrm{H}, \mathrm{s}),-0.20(3 \mathrm{H}, \mathrm{s}),-0.70(3 \mathrm{H}, \mathrm{s})$; (Found: C, 70.90; $\mathrm{H}, 9.05 . \mathrm{C}_{27} \mathrm{H}_{40} \mathrm{SSiO}_{2}$ requires $\mathrm{C}, 71.05 ; \mathrm{H}, 8.77$.)

Preparation of 8-t-butyldimethylsilyloxy-1-thiophenoxymethyl-2,5,4,8a-tetramethyl-( $\Delta{ }^{1,2}$, $\Delta^{3,4}$ )-decalin (11). A solution of the sulfoxides (10) (192 mg, $\left.0.421 \mathrm{mmol}\right)$ in dry DME (4 ml) was added dropwise to a cooled (ice-bath) suspension of lithium aluminium hydride (75 $\mathrm{mg}$, $1.974 \mathrm{mmol})$ in dry DME $(2 \mathrm{ml})$ in a flame dried 25-ml two-neck flask fitted with a reflux condenser. When addition was complete, the reaction mixture was refluxed for 3-4 $\mathrm{h}$ under nitrogen. Then it was cooled down and quenched by addition of saturated sodium sulphate solution $(5 \mathrm{ml})$. The reaction mixture was filtered through a pad of celite, which was washed with a further portion of ether $(25 \mathrm{ml})$. The filtrate was dried $\left(\mathrm{Na}_{2} \mathrm{SO}_{4}\right)$ and concentrated. The residue was purified by chromatography (8:1 Petrol/ Ether) o afford the product as a viscous oil (150 mg, 80\%). The compound had: $\delta_{\mathrm{H}}\left(\mathrm{CDCl}_{3} ; 300 \mathrm{MHz}\right) 7.12(5 \mathrm{H}, \mathrm{m}), 5.90(1 \mathrm{H}, \mathrm{m}), 5.72(1$ $\mathrm{H}, \mathrm{m}), 4.38(\sim 0.5 \mathrm{H}, \mathrm{dd}, \mathrm{J}=12.0 \mathrm{~Hz}, \mathrm{~J}=6.0 \mathrm{~Hz}), 4.06(\sim 0.5 \mathrm{H}, \mathrm{bs}, \mathrm{w} / 2=9.0 \mathrm{~Hz}), 4.15(1 \mathrm{H}, \mathrm{q}$, $\mathrm{J}=13.0 \mathrm{~Hz}), 3.65(1 \mathrm{H}, \mathrm{q}, \mathrm{J}=15.0 \mathrm{~Hz}), 2.62(1 \mathrm{H}, \mathrm{m}),\{1.78$ and 1.65$\}$ (3H, two s's), 2.00-1.00 (4H, $\mathrm{m}), 1.55$ and $1.32(3 \mathrm{H}$, two s's), $\{1.18$ and 1.12$\}$ and $\{0.95$ and 0.92$\}(6 \mathrm{H}, \mathrm{s}$ 's), $\{0.84$ and 0.80$\}$ (9H, s's), $\{0.12$ and 0.10$\}$ and $\{0.05$ and 0.03$\}$ (6H, s's). (Found HRMS 443.2804, $\mathrm{C}_{27} \mathrm{H}_{42} \mathrm{SSiO}$ $+\mathrm{H}$ requires 443.2804)

Preparation of 5-[2,4,4-trimethyl-1-hydroxycyclohex-3-enyl]-3-methylpent-(Z)-4-en-1-yn-3ol (14). The silylether (9) (400 mg, $1.117 \mathrm{mmol})$ was dissolved in dry THF (8 ml) and the solution was treated with a solution of TBAF in THF $(1 \mathrm{M}, 1.3 \mathrm{ml})$ at room temperature. The solution was stirred at room temperature for $30 \mathrm{~min}$ and then was diluted with water $(20 \mathrm{ml})$. The mixture was extracted with ether $(2 \times 25 \mathrm{ml})$, the combined organics were washed with brine $(25$ $\mathrm{ml})$ and dried $\left(\mathrm{Na}_{2} \mathrm{SO}_{4}\right)$. Evaporation and chromatography (3:1 petrol/ ether) gave the desired product as a pale yellow oil $(218 \mathrm{mg}, 80 \%) ; \delta_{\mathrm{H}}\left(\mathrm{CDCl}_{3} ; 300 \mathrm{MHz}\right) 5.80(1 \mathrm{H}, \mathrm{d}, \mathrm{J}=12.0 \mathrm{~Hz}), 5.45$ $(1 \mathrm{H}, \mathrm{d}, \mathrm{J}=12.0 \mathrm{~Hz}), 3.90(1 \mathrm{H}, \mathrm{m}), 2.46(1 \mathrm{H}, \mathrm{s}), 1.90-1.20(4 \mathrm{H}, \mathrm{m}), 1.75(3 \mathrm{H}, \mathrm{s}), 1.60(3 \mathrm{H}, \mathrm{s})$, $1.00(3 \mathrm{H}, \mathrm{s}), 0.95(3 \mathrm{H}, \mathrm{s})$.

Preparation of 5-[2,4,4-trimethyl-1-benzyloxymethyloxycyclohex-3-enyl]-3-methylpent-(Z)4-en-1-yn-3-ol (15). Alcohol (14) (167 mg, $0.716 \mathrm{mmol}$ ) was dissolved in dry dichloromethane $(4 \mathrm{ml})$ and was sequentially treated with $\mathrm{N}, \mathrm{N}$-diisopropylethylamine $(160 \mu 1,0.931 \mathrm{mmol})$ and benzyloxymethylchloride $(130 \mu 1,1.76 \mathrm{mmol})$ at room temperature. The reaction mixture was stirred for six hours and then was diluted with dichloromethane $(30 \mathrm{ml})$. The mixture was washed with bench $\mathrm{HCl}(15 \mathrm{ml})$, water $(15 \mathrm{ml})$ and brine $(15 \mathrm{ml})$. Evaporation and purification of the residue by chromatography $(5: 1$, petrol/ether) gave the product (15) as a pale yellow oil (202 mg, 80\%). The compound had: $v_{\max } / \mathrm{cm}^{-1}$ (FT) (thin film) 3450, 3300, 2100; $\delta_{\mathrm{H}}\left(\mathrm{CDCl}_{3}\right.$; $300 \mathrm{MHz}) 7.25(5 \mathrm{H}, \mathrm{bs}), 5.84(1 \mathrm{H}, \mathrm{d}, \mathrm{J}=12.0 \mathrm{~Hz}), 5.66(1 \mathrm{H}, \mathrm{d}, \mathrm{J}=12.0 \mathrm{~Hz}), 4.80$ (2H, d, J=3.0 
Hz), 4.60 (2H, bs), 4.15 (1H, bt), $2.50(1 \mathrm{H}, \mathrm{s}), 1.90-1.20(4 \mathrm{H}, \mathrm{m}), 1.78(3 \mathrm{H}, \mathrm{s}), 1.52(3 \mathrm{H}, \mathrm{s}), 1.00$ $(3 \mathrm{H}, \mathrm{s}), 0.95(3 \mathrm{H}, \mathrm{s})$.

Cyclisation of alcohol (15). The alcohol (15) (180 $\mathrm{mg}, 0.508 \mathrm{mmol}$ ) was cyclised in the usual manner to give a mixture of sulfoxides (16) $(164 \mathrm{mg}, 70 \%)$. A separable component had: $\delta_{\mathrm{H}}$ $\left(\mathrm{CDCl}_{3} ; 300 \mathrm{MHz}\right) 7.68(2 \mathrm{H}, \mathrm{m}), 7.52(3 \mathrm{H}, \mathrm{m}), 7.20(5 \mathrm{H}, \mathrm{bs}), 6.00(1 \mathrm{H}, \mathrm{s}), 5.90(2 \mathrm{H}$, overlapping d's, J=8.0 Hz), $4.70(2 \mathrm{H}, \mathrm{d}, \mathrm{J}=8.0 \mathrm{~Hz}), 4.20(2 \mathrm{H}, \mathrm{d}, \mathrm{J} \approx 2.0 \mathrm{~Hz}), 4.10(1 \mathrm{H}, \mathrm{m}), 2.35$ $(3 \mathrm{H}, \mathrm{s}), 1.90-1.40(4 \mathrm{H}, \mathrm{m}), 1.35$ (3H, s), $1.24(3 \mathrm{H}, \mathrm{s}), 1.18$ (3H, s); m/z (EI): 399, 383, 332, 91.

Preparation of 5-[2,4,4-trimethyl-1-acetoxycyclohex-3-enyl]-3-methylpent-(Z)-4-en-1-yn-3ol (17). The foregoing alcohol (14) $(150 \mathrm{mg}, 0.641 \mathrm{mmol})$ was dissolved in dry methylene chloride $(5 \mathrm{ml})$ and the solution was cooled to $0^{\circ} \mathrm{C}$ followed by addition of acetic anhydride $(0.5$ $\mathrm{ml}, 5.304 \mathrm{mmol})$, pyridine $(0.5 \mathrm{ml}, 6.113 \mathrm{mmol})$ and DMAP $(10 \mathrm{mg}, 0.082 \mathrm{mmol})$. The solution was stirred with slow warming up to room temperature over about $4 \mathrm{~h}$. The reaction mixture was then diluted with methylene chloride $(25 \mathrm{ml})$ and was washed with sodium bicarbonate solution $(20 \mathrm{ml})$, water $(20 \mathrm{ml}), 2 \mathrm{M} \mathrm{HCl}(20 \mathrm{ml})$ and finally brine $(20 \mathrm{ml})$. The solution was dried $\left(\mathrm{Na}_{2} \mathrm{SO}_{4}\right)$ and then evaporated to yield the product (17), as a pale yellow oil (167 $\left.\mathrm{mg}, 95 \%\right)$. The compound had: $v_{\max } / \mathrm{cm}^{-1}$ (FT) (thin film) 3478, 3305, 2100, 1745; $\delta_{\mathrm{H}}\left(\mathrm{CDCl}_{3} ; 300 \mathrm{MHz}\right) 5.90$ $(1 \mathrm{H}, \mathrm{d}, \mathrm{J}=12.0 \mathrm{~Hz}), 5.62(1 \mathrm{H}, \mathrm{d}, \mathrm{J}=12.0 \mathrm{~Hz}), 5.15(1 \mathrm{H}, \mathrm{bt}), 2.50(1 \mathrm{H}, \mathrm{s}), 2.02$ (3H, s), 1.90-1.20 $(4 \mathrm{H}, \mathrm{m}), 1.75(3 \mathrm{H}, \mathrm{s}), 1.58(3 \mathrm{H}, \mathrm{s}), 1.00(3 \mathrm{H}, \mathrm{s}), 0.95(3 \mathrm{H}, \mathrm{s})$.

Cyclisation of alcohol (17). The alcohol (17) (150 $\mathrm{mg}, 0.524 \mathrm{mmol})$ was cyclised as above to give the products (18) $(141 \mathrm{mg}, 70 \%)$. A separable component had: $v_{\max } / \mathrm{cm}^{-1}$ (FT) (thin film) $1742, \delta_{\mathrm{H}}\left(\mathrm{CDCl}_{3} ; 300 \mathrm{MHz}\right) 7.72(2 \mathrm{H}, \mathrm{m}), 7.48(3 \mathrm{H}, \mathrm{m}), 5.95(1 \mathrm{H}, \mathrm{s}), 5.80$ (2H, overlapping d's, J=6.0 Hz), $5.10(1 \mathrm{H}, \mathrm{m}),\{2.35$ and 2.30$\}(3 \mathrm{H}, \mathrm{s}),\{2.02$ and 2.00$\}(3 \mathrm{H}, \mathrm{s}), 1.90-1.40(4 \mathrm{H}$, m), $1.35(3 \mathrm{H}, \mathrm{s}), 1.28(3 \mathrm{H}, \mathrm{s}), 1.22(3 \mathrm{H}, \mathrm{s}) ; \mathrm{m} / \mathrm{z}(\mathrm{EI}): 341,324,125,77,43$.

Reduction of sulfoxides (18) by lithium aluminium hydride. The sulfoxides (18) (120 mg, $0.312 \mathrm{mmol}$ ) were reduced with lithium aluminium hydride $(47 \mathrm{mg}, 1.252 \mathrm{mmol})$ as described above to give the product (19) as a pale yellow oil (81 $\mathrm{mg}, 80 \%)$ after purification by chromatography (3:1 petrol:ether). The compound had: $v_{\max } / \mathrm{cm}^{-1}$ (FT) (thin film) $3360, \delta_{\mathrm{H}}$ $\left(\mathrm{CDCl}_{3} ; 300 \mathrm{MHz}\right) 7.15(7 \mathrm{H}, \mathrm{m}), 4.15(2 \mathrm{H}, \mathrm{s}), 3.48(2 \mathrm{H}, \mathrm{t}, \mathrm{J}=6.0 \mathrm{~Hz}), 2.50(3 \mathrm{H}, \mathrm{s}), 2.35(3 \mathrm{H}, \mathrm{s})$, 1.8-1.5 (4H, m), $1.40(6 \mathrm{H}, \mathrm{s}) ; \mathrm{m} / \mathrm{z}(\mathrm{EI}): 328\left(\mathrm{M}^{+}\right), 310,123,109,77$.

\section{Acknowledgements}

The author wishes to thank the University of Manchester for financial support and Professor J. K. Sutherland for his advice during the course of this work. 


\section{References}

1. Bhat, S. V.; Bajwa, B. S.; Dornauer, H.; de Souza, N. J.; Fehlhaber, H. W. Tetrahedron Lett. 1977, 1669.

2. $\quad$ Rupp, R. H.; de Souza, N. J.; Dohadwalla A. N. In Forskolin: Its Chemical, Biological and Medical Potential, Hoechst India Limited, Bombay, 1985. (b) Seamon, K. B.; Daly, J. W. Adv. Cyclic Nucleotide Res. 1986,20, 1. Khandelwal, Y.; Rajeshwari, K.; Rajagopalan, R.; Swamy, L.; Dohadwalla, A. N.; de Souza, N. J.; Rupp, R. H. J. Med. Chem., 1988, 31, 1872. Colombo, M. I.; Zinczuk, J.; Ruveda, E. A. Tetrahedron, 1992, $48,963$.

3. Levin, J. I. Tetrahedron Lett., 1996, 37, 3079.

4. $\quad$ Leclaire, M.; Levet, R.; Péricaud, F.; Ricard, L.; Lallemand, J. Y. Tetrahedron, 1996, 52, 7703.

5. Lee, K.; Lee, C.; Kim, H. Bull. Korean Chem. Soc., 1996, 17, 773

6. Liu, J.; Shang, X.; Heterocycles, 1997, 44, 143.

7. Anies, A.; Pancrazi, J. Y.; Lallemand, T.; Prangé, Bull. Soc. Chim. Fr., 1997, 134, 183.Anies, A. Pancrazi, J. Y. Lallemand, T. Prangé, Bull. Soc. Chim. Fr., 1997, 134, 203.

8. Hanna, P. Wlodyka, J. Org. Chem., 1997, 62, 6985.

9. Behnke, S. Hamm, L. Hennig, P. Welzel, Tetrahedron Lett., 1997, 38, 7059.

10. Kim, K. Lee, H. Kim, Bull. Korean Chem. Soc., 1997, 18, 1139.

11. Lee, K.; Kim, H. Bull. Korean Chem. Soc., 1998, 19, 921.

12. Liu, H. J.; Shang, X. Heterocycles, 1999, 50, 1105.

13. Behnke, L. Hennig, M. Findeisen, P. Welzel, D. Müller, M. Thormann, H.-J. Hofmann, Tetrahedron, 2000, 56, 1081.

14. Okamura, W. H.; Peter, R.; Reischl, W. J. Am. Chem. Soc., 1985, 107, 1034.

15. Corey, J.; Venkateswarlu, A. J. Am. Chem. Soc., 1972, 94, 6190.

16. Sugihara, H.; Tanikaga, R.; Kaji, A. Synthesis, 1978, 881.

17. Khodabocus, A.; Shing, T. K. M.; Sutherland, J. K.; Williams, J. G. J. Chem. Soc., Chem. Comm., 1989, 783. 